International Journal of Library \& Information Science (IJLIS)

Volume 8, Issue 2, May-August 2019, pp. 23-26, Article ID: IJLIS_08_02_003

Available online at

http://iaeme.com/Home/issue/IJLIS?Volume=8\&Issue2

Journal Impact Factor (2019): 9.8614 (Calculated by GISI) www.jifactor.com

ISSN Print: 2277-3533 and ISSN Online: 2277-3584

(C) IAEME Publication

\title{
APPLICATION OF LIBMAS IN THE COLLEGE LIBRARIES
}

\author{
Suguna L.S. \\ Research Scholar, Dept. of Library \& Information Science \\ University of Kerala, India
}

\begin{abstract}
This study examined the impact of Libmas on library services in Kerala. A selfdesigned questionnaire was distributed to both professional and para-professional staff of the libraries. Collected data was analyzed using descriptive statistical method. The results of the analysis showed that Libmas has favorably impacted their libraries.
\end{abstract}

Key words: Library software; Library services; Academic libraries

Cite this Article: Suguna L.S., Application of Libmas in the College Libraries, International Journal of Library \& Information Science, 8(1), 2019, pp. 23-26.

$\mathrm{http}: / /$ iaeme.com/Home/issue/IJLIS?Volume=8\&Issue2

\section{INTRODUCTION}

Handling large collections and serving a huge clientele makes Library management a complex issue. To carry out various operations in a library effectively, library automation is essential. Amazing developments in the sphere of communication technology have radically redefined acquisition, processing, storage, retrieval and dissemination of information ${ }^{1}$. Computers in libraries have been used widely for acquisition, cataloguing, classification, circulation, serials control, and information storage and retrieval activities. Libraries all over the world have realized the need to move from their manual practices to software operations ${ }^{2}$. Various collections owned by library are books, journals, magazines, DVDs etc. Library computers can be connected together with various sections for sharing and saving daily operations. Library software can do various tasks at a time.

Library users can search a book, view available book list, hold book, etc. Library staff can store bibliographic records in database, create patron database, etc. A number of software packages have been developed for use in the management and dissemination of information in libraries. So many softwares are available and many of them are being used by libraries worldwide ${ }^{3}$. Utilizing all these advantageous factors VOLKS ELECTRONICS have developed a windows-based Library Management software-LiBMAS. The development of Libmas software is steered by a growing number of libraries throughout the world. Its remarkable feature continues to meet the needs of its libraries. In the recent years, many libraries in Kerala are increasingly adopting Libmas. This survey is to examine the impact of Libmas on library services in Kerala. 


\section{Objectives of the study}

1. To find out the satisfaction level of selected libraries in using Libmas.

2. To find out the challenges faced by the library staff and users in using Libmas.

3. To suggest ways of improving the use of Libmas by librarians and users in the future.

\section{METHODOLOGY}

The sample population of this questionnaire-based survey study comprised the professional and para-professional librarians in the libraries using Libmas. Out of the total of 50 questionnaires distributed, 47 were returned and used for the data analysis. With the employment of descriptive statistics, table frequency was used to present quantitative analysis of the facts gathered from the questionnaire administered on the respondents.

\section{ANALYSIS}

Libraries have materials arranged in a specified order according to a library classification system, so that items may be located quickly and collections may be browsed efficiently. In order to save the time of the user most of the libraries are being automated. This extra time can lead to more programs being facilitated in the library and make library staff available to answer reference questions and help people who having trouble researching or finding the right information. The process requires effective software to handle most of the tasks in libraries. Automation of the library allows for an improvement in the variety, amount and quality of materials that are available in the library's collection. LIBMAS is a complete barcode integrated Library Automation of software. The study (Table 1) shows that Limas is implemented more in Colleges followed by University Department libraries.

Table 1 Implimentation of Libmas

\begin{tabular}{|c|l|c|}
\hline Sl.No. & \multicolumn{1}{|c|}{ Category } & Count \\
\hline 1 & Colleges & 20 \\
\hline 2 & University Departments & 6 \\
\hline 3 & Hospital s & 2 \\
\hline 4 & Archives & 1 \\
\hline 5 & Banks & 4 \\
\hline 6 & Private Institutes & 2 \\
\hline \multicolumn{2}{|c|}{ Total } \\
\hline
\end{tabular}

\section{Impact of Libmas}

Table 2 reveals that $36(76.6 \%)$ respondents strongly agreed that Libmas software has impacted library services. More so, 35(74.5\%) respondents strongly agreed that Libmas is helpful in charging and discharging of books and library materials. Also, 31(66.0\%) respondents strongly agreed to the fact that Libmas has helped in moving most of the libraries to the next level. 
Application of Libmas in the College Libraries

Table 2 Impact of Libmas on library services

\begin{tabular}{|l|c|c|c|c|c|}
\hline & $\begin{array}{c}\text { SA } \\
\text { Freq. \% }\end{array}$ & $\begin{array}{c}\text { A } \\
\text { Freq. \% }\end{array}$ & $\begin{array}{c}\text { D } \\
\text { Freq. \% }\end{array}$ & $\begin{array}{c}\text { SD } \\
\text { Freq. \% }\end{array}$ & $\begin{array}{c}\text { Total } \\
\text { \% }\end{array}$ \\
\hline $\begin{array}{l}\text { Libmas has impacted } \\
\text { our library services. }\end{array}$ & $36(76.6 \%)$ & $11(23.4 \%)$ & $0(0.0 \%)$ & $0(0.00 \%)$ & 47 \\
\hline $\begin{array}{l}\text { Libmas is helpful in } \\
\text { charging and } \\
\text { discharging of books } \\
\text { and library materials }\end{array}$ & $35(74.5 \%)$ & $12(25.5 \%)$ & $0(0.0 \%)$ & $0(0.0 \%)$ & 47 \\
\hline $\begin{array}{l}\text { Libmas has helped in } \\
\text { moving most libraries } \\
\text { to the next level }\end{array}$ & $31(66.0 \%)$ & $16(34.0 \%)$ & $0(0.0 \%)$ & $0(0.0 \%)$ & 47 \\
\hline $\begin{array}{l}\text { Libmas makes } \\
\text { acquisitions system for } \\
\text { library simple }\end{array}$ & $25(53.2 \%)$ & $22(46.8 \%)$ & $0(0.0 \%)$ & $0(0.0 \%)$ & 47 \\
\hline $\begin{array}{l}\text { Libmas makes catalog } \\
\text { facility available }\end{array}$ & $31(66 \%)$ & $16(34 \%)$ & $0(0.0 \%)$ & $0(0.0 \%)$ & 47 \\
\hline
\end{tabular}

$\mathrm{SA}=$ Strongly Agree, $\mathrm{A}=$ Agree, $\mathrm{D}=$ Disagree, $\mathrm{SD}=$ Strongly Disagree

\section{Satisfaction with Libmas}

Table 3 presents the satisfaction of library professionals with Libmas. Thirty four $(72.34 \%)$ respondents strongly agreed that they are satisfied with Libmas in carrying out library services. Thirty $(63.83 \%)$ respondents strongly agreed that they would recommend the use of Libmas to other libraries and 20(42.6\%) respondents strongly agreed that they find Libmas dependable. Also, 28(59.57\%) respondents strongly agreed that overall, they are satisfied with the use of Libmas.

Table 3 Satisfaction with the use of Libmas

\begin{tabular}{|l|c|c|c|c|c|}
\hline & $\begin{array}{c}\text { SA } \\
\text { Freq. \% }\end{array}$ & $\begin{array}{c}\text { A } \\
\text { Freq. \% }\end{array}$ & $\begin{array}{c}\text { D } \\
\text { Freq. \% }\end{array}$ & $\begin{array}{c}\text { SD } \\
\text { Freq. \% }\end{array}$ & $\begin{array}{c}\text { Total } \\
\text { \% }\end{array}$ \\
\hline $\begin{array}{l}\text { I am satisfied with } \\
\text { Libmas for } \\
\text { carrying } \\
\text { out library } \\
\text { services. }\end{array}$ & $34(72.34 \%)$ & $13(27.66 \%)$ & $0(0.0 \%)$ & $0(0.0 \%)$ & 47 \\
\hline $\begin{array}{l}\text { I would } \\
\text { recommend } \\
\text { Libmas to other } \\
\text { libraries }\end{array}$ & $30(63.83 \%)$ & $17(36.17 \%)$ & $0(0.0 \%)$ & $0(0.0 \%)$ & 47 \\
\hline $\begin{array}{l}\text { I find Libmas } \\
\text { dependable }\end{array}$ & $20(42.6 \%)$ & $27(57.4 \%)$ & $0(0.0 \%)$ & $0(0.0 \%)$ & 47 \\
\hline $\begin{array}{l}\text { Overall, I am } \\
\text { satisfied with } \\
\text { Libmas }\end{array}$ & $28(59.57 \%)$ & $19(40.43 \%)$ & $0(0.0 \%)$ & $0(0.0 \%)$ & 47 \\
\hline
\end{tabular}

$\mathrm{SA}=$ Strongly Agree, $\mathrm{A}=$ Agree, $\mathrm{D}=$ Disagree, $\mathrm{SD}=$ Strongly Disagree 


\section{Challenges in using Libmas}

Table 4 gives the challenges with Libmas. The maintenance cost of Libmas is pretty low and there is seemingly the required expertise in handling the software in the colleges. It is also seen that there is negligible software related problems including installation of the software.

Table 4 Challenges encountered with the use of Libmas

\begin{tabular}{|l|c|c|c|c|c|}
\hline & $\begin{array}{c}\text { SA } \\
\text { Freq. \% }\end{array}$ & $\begin{array}{c}\text { A } \\
\text { Freq. \% }\end{array}$ & $\begin{array}{c}\text { D } \\
\text { Freq. \% }\end{array}$ & $\begin{array}{c}\text { SD } \\
\text { Freq. \% }\end{array}$ & $\begin{array}{c}\text { Total } \\
\text { \% }\end{array}$ \\
\hline $\begin{array}{l}\text { High cost of } \\
\text { maintenance }\end{array}$ & $0(0.0 \%)$ & $1(2.1 \%)$ & $41(87.25)$ & $5(10.6 \%)$ & 47 \\
\hline Inadequate expertise & $0(0.0 \%)$ & $4(8.5 \%)$ & $37(78.25)$ & $5(12.8 \%)$ & 47 \\
\hline $\begin{array}{l}\text { Software problems } \\
\text { e.g. } \\
\text { malfunctioning, } \\
\text { hanging }\end{array}$ & $1(2.15 \%)$ & $2(4.3 \%)$ & $39(83.0 \%)$ & $5(10.6 \%)$ & 47 \\
\hline $\begin{array}{l}\text { Difficulties in } \\
\text { installing Libmas }\end{array}$ & $1(2.1 \%)$ & $0(0.0 \%)$ & $29(61.7 \%)$ & $17(36.2 \%)$ & 47 \\
\hline
\end{tabular}

$\mathrm{SA}=$ Strongly Agree, $\mathrm{A}=$ Agree, $\mathrm{D}=$ Disagree, $\mathrm{SD}=$ Strongly Disagree

\section{CONCLUSION}

Libmas is effective software that is recommended for use in libraries that have not adopted software for library automation. As Libmas continues to receive wide acceptance by the user community, it is expected that the programmer and the user community will be positive in further improving the software to make it even user friendly.

\section{REFERENCES}

[1] Volks. (n.d.). Libmas. Retrieved July 26, 2019, from Volks electronics: http://www.libmas.com/aboutus.htm

[2] Uzomba EC Oyebola OJ and Izuchukwu AC, The Use and Application of Open Source Integrated Library System in Academic Libraries in Nigeria: Koha Example. Library Philosophy and Practice (e-Journal), Paper 1250 (2015)1-37.

[3] Kumar V and Jasimudeen S, Adoption and user perceptions of Koha library management system in India. Annals of Library and Information Studies, 59 (4) (2012) 1-15. 